\title{
Brown adipose tissue activity in pyrexial cases of cot death
}

\author{
M E J LEAN, G JENNINGS \\ From the Dunn Nutrition Laboratory, Medical Research Council and University of Cambridge, Cambridge
}

SUMMARY Brown adipose tissue was investigated in two cases of cot death in which core temperatures were above $40^{\circ} \mathrm{C}$ on arrival at the mortuary. Evidence was obtained from mitochondrial $\left(8-{ }^{3} \mathrm{H}\right)$ guanosine diphosphate (GDP) binding and oxygen uptake of active thermogenesis with uncoupled mitochondrial respiration which was recoupled by GDP. Thermogenic capacity of brown adipose tissue, estimated by radioimmunoassay of the specific mitochondrial membrane "uncoupling protein" responsible for heat production, was similar to that measured in other infants or in experimental animals acclimated to moderately warm conditions $\left(23^{\circ} \mathrm{C}\right)$.

Brown adipose tissue thermogenesis, occurring inappropriately in a warm, well insulated infant, could be a cause of some cases of cot death.

Some cot deaths, or sudden infant death syndrome (SIDS), have recently been considered to be related to problems with thermoregulation, resulting in overheating. ${ }^{12}$ Overinsulation with clothes or bedding may be an important factor, especially if the room temperature is kept warm, but excessive endogenous heat production could also play a part. Suggestions as to the source of excess heat production have not been made, but Naeye and coworkers reported increased amounts of brown adipose tissue in cot death infants. ${ }^{3}$

The possibility that the activity of brown adipose tissue could, in some instances, be involved in the mechanisms leading up to cot death by generating heat inappropriately is difficult to explore. We have, however, had the opportunity of investigating the properties of brown adipose tissue in two pyrexial cases of cot death from which it was possible to obtain fresh tissue. The results suggest that brown adipose tissue is thermogenically active in such cases. Although its activity may not be different from that of normal infants, thermogenesis in this situation is inappropriate and could indeed contribute to death.

\section{Material and methods}

The two infants were both male and aged 5 months: they had died at home in their cots between 7-8 am. Body weights were 7 and $8 \mathrm{~kg}$, respectively. These were both typical cases of cot death: previous developmental history and health were unremarkable and no

Accepted for publication 25 May 1989 underlying cause of death was found. The rectal temperature in each case, however, was above $40^{\circ} \mathrm{C}$ on arrival at hospital, and postmortem examinations were carried out within two hours of death.

Adipose tissue was removed from sites of axillary, cervical, interscapular and perirenal brown adipose tissue, and cytochrome oxidase activity (E.C.1.9.3.1) was measured as an index of mitochondrial mass by a spectrophotometric method. ${ }^{4}$ For electron microscopical examination, tissue was fixed in osmium tetroxide and embedded in Spurr's resin and sections were stained with uranyl acetate and lead citrate. Mitochondrial preparations were prepared within two hours, and thermogenic activity was assessed by a $\left(8-{ }^{3} \mathrm{H}\right)$ guanosine diphosphate (GDP) binding assay, according to previously described methods. ${ }^{5}$ Mitochondrial uncoupling protein content was measured as an index of thermogenic capacity using a solid phase radioimmunoassay with a lower limit of detection of $0.8 \mu \mathrm{g} / \mathrm{mg}$ total mitochondrial protein, using a specific rabbit anti-human uncoupling protein antiserum. ${ }^{6}$ In case 2 direct measurements of mitochondrial respiration were made using an oxygen electrode (YSI Co, Ohio, USA) at $25^{\circ} \mathrm{C}$ with $10 \mathrm{mM} \alpha-$ glycerophosphate as substrate in a medium (pH 7.1) containing $100 \mathrm{mM}$ sucrose, $10 \mathrm{mM}$ glycylglycine, $5 \mu \mathrm{M}$ rotenone and bovine serum albumin $2.5 \mathrm{mg} / \mathrm{ml}$. Initial respiration rate was obtained and GDP added ( $1 \mathrm{mM}$ final concentration) to obtain the fully coupled respiration rate. Finally, $5 \mu \mathrm{M}$ of the uncoupling agent FCCP (Sigma Chemical Co, Poole, Dorset) was added to estimate fully uncoupled oxygen uptake. 
Table Biochemical results on brown adipose tissue obtained within two hours of death from two cot death infants, and comparison with 7 published figures in infants and mice

\begin{tabular}{|c|c|c|c|c|}
\hline & $\begin{array}{l}\text { Cytochrome oxidase activity } \\
(\mu \mathrm{mol} / \mathrm{min} / \mathrm{g})\end{array}$ & $\begin{array}{l}\text { Uncoupling protein } \\
\text { ( } \mu \mathrm{g} / \mathrm{mg} \text { mitochodrial protein) }\end{array}$ & $\begin{array}{l}\text { GDP binding activity } \\
\text { ( } \mathrm{p} \text { mol/mg mitochondrial protein) }\end{array}$ & $\begin{array}{l}\text { Change in } \mathrm{O}_{2} \\
\text { uptake from } \mathrm{GD}\end{array}$ \\
\hline $\begin{array}{l}\text { Case 1: } \\
\text { Axillary } \\
\text { Cervical } \\
\text { Perirenal } \\
\text { Interscapular }\end{array}$ & $\begin{array}{r}246 \\
202 \\
94 \\
18\end{array}$ & $\begin{array}{r}22 \\
23 \\
11 \\
7\end{array}$ & $\begin{array}{r}147 \\
149 \\
133 \\
91\end{array}$ & $\begin{array}{l}- \\
-\end{array}$ \\
\hline $\begin{array}{l}\text { Case 2: } \\
\text { Axillary } \\
\text { Perirenal }\end{array}$ & $\begin{array}{l}66 \\
23\end{array}$ & $\begin{array}{r}10 \\
9\end{array}$ & $\begin{array}{l}129 \\
104\end{array}$ & $\begin{array}{l}-23 \% \\
-9 \%\end{array}$ \\
\hline $\begin{array}{l}\text { Human infants }{ }^{*} \text { : } \\
\text { Axillary } \\
\text { Perirenal }\end{array}$ & - & $\begin{array}{r}15 \pm 11 \\
9 \pm 11\end{array}$ & - & - \\
\hline $\begin{array}{l}\text { Mice: } 3 \text { months: } \dagger \\
33^{\circ} \mathrm{C}-22^{\circ} \mathrm{C}\end{array}$ & $40-178$ & $9-43$ & $69-200$ & \\
\hline
\end{tabular}

Mean results obtained using the same methods on mitochondria:

*From 17 infants who died suddenly from a variety of causes ${ }^{6}$

+From the interscapular brown adipose tissue (the principal site) of mice housed at $33^{\circ} \mathrm{C}$ (warm) and at $22^{\circ} \mathrm{C}(\mathrm{cool})$ room temperatures ${ }^{17}$

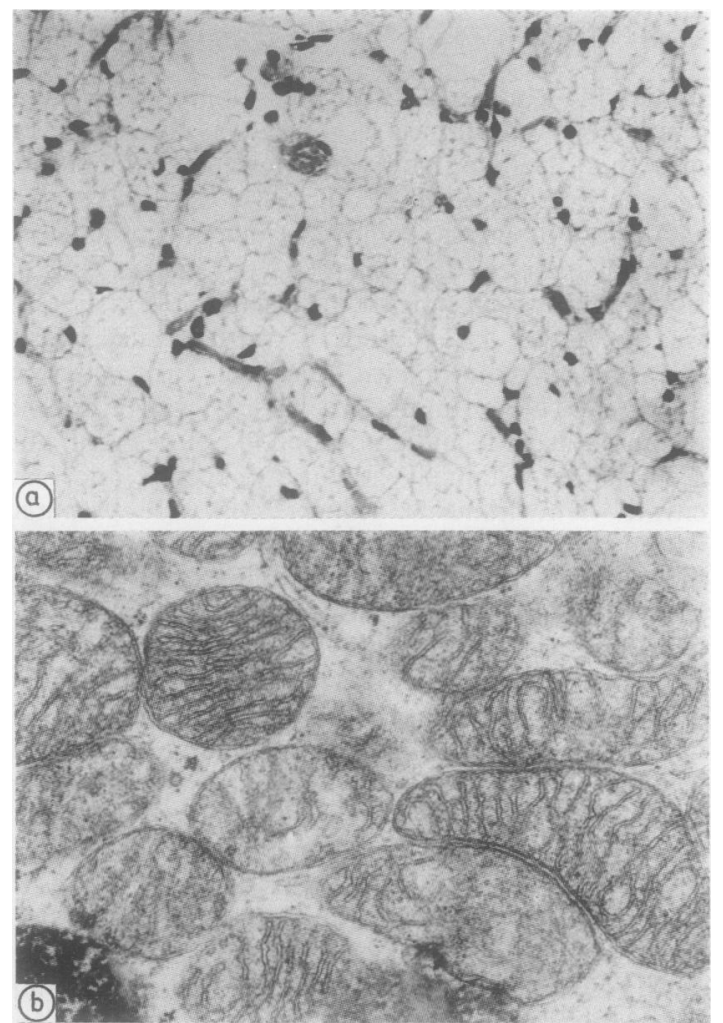

Fig 1 Photomicrographs of perirenal adipose tissue from a 5 month old boy (case 1) after cot death. (a) haematoxylin and eosin stain showing high vascularity; (b) electron micrograph showing mitochondrial structure.

\section{Results}

Biochemical measurements made on fresh brown adipose tissue from cases 1 and 2 are shown in the table: histological appearances were typical of active brown adipose tissue, with high vascularity, roundede nuclei, and multivesicular cytoplasm packed with mitochondria, and without evidence of necrosis (fig 1 ) Uncoupling protein content was significantly correlated with cytochrome oxidase $(r=0.97, n=6, p<$ $0.001)$ and GDP binding activity $(r=0.85, p<$ 0.02 ). All were highest in axillary and cervical sites. Scatchard analyses (fig 2) at GDP concentrations of $0.5-25 \mu \mathrm{M}$ were interpreted as indicating single site mitochondrial GDP binding characteristics with dis-

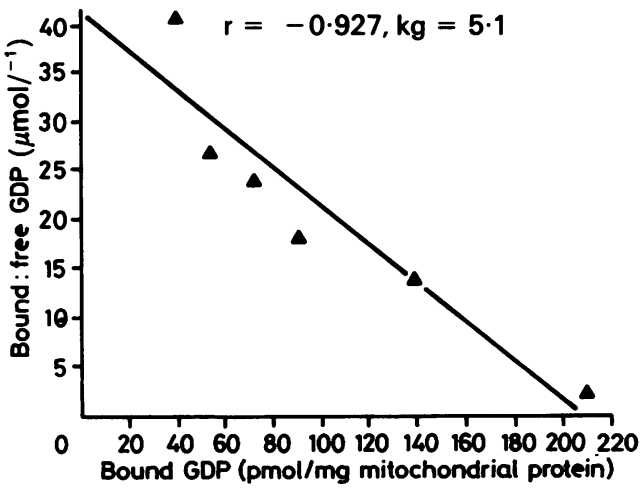

Fig 2 Scatchard plot of GDP binding to human brown adipose tissue mitochondria. (Case 1, perirenal.) 


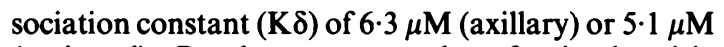
(perirenal). Basal oxygen uptake of mitochondria from case 1 was similar to that after the addition of the uncoupling agent $\mathrm{FCCP}$, indicating substantially uncoupled respiration in the basal state. Addition of GDP produced a clear reduction in oxygen uptake, indicating recoupling of respiration.

\section{Discussion}

The similarity of brown adipose tissue in human infants to the "hibernating gland" of small animals was recognised by Hatai in $1902 .^{7}$ It is present in widespread intra-abdominal and paravascular sites in man, usually distinguishable from subcutaneous white adipose tissue by its darker colour and firmer consistency, features which derive from lower lipid content, higher cytochrome content, and greater vascularity. Its thermogenic function seems to be the same in all species studied, through uncoupled respiration regulated by catecholamines, dependent on the unique mitochondrial uncoupling protein. In a previous study we showed activation of brown adipose tissue thermogenesis and increased mitochondrial uncoupling protein content in adipose tissue from adults exposed to high circulating catecholamines from phaeochromocytoma. ${ }^{8}$

Uncoupling protein is generally present in detectable amounts in mitochondria from infant brown adipose tissue. ${ }^{6}$ The concentration was similar in 10 cot death infants (perirenal $6.6 \pm 1.6 \mu \mathrm{g} / \mathrm{mg}$, axillary $11.7 \pm 2.2 \mu \mathrm{g} / \mathrm{mg}$ protein) to the remainder of a group of 17 infants who died suddenly from a variety of causes (table), which does not suggest any chronic stimulation. Acute sympathetic stimulation of brown adipose tissue may still contribute to some cot deaths, however. Increased synthesis of uncoupling protein in response to cooling or to noradrenaline occurs only over a period of two days or more, although the mRNA that codes for synthesis of the uncoupling protein appears much more rapidly. ${ }^{9}$ Cytochrome oxidase and GDP binding activities in both babies reported here showed characteristics similar to those in other species and suggested a thermogenic activity roughly equivalent to the brown adipose tissue of mice acclimated to warm laboratory conditions, being greatest in the axillary and cervical sites, which in primates comprise the largest single block of brown adipose tissue.

Naeye interpreted an increased amount of brown adipose tissue in cot deaths as a result of tissue hypoxia, possibly indicating pulmonary disease. ${ }^{3}$ Hypoxia, however, usually leads to a suppression of oxygen utilisation for thermogenesis ${ }^{10}$ as this could only continue at the expense of other vital organs. Active thermogenesis, such as we have shown near the time of death in two cases of cot death, involves increased oxygen uptake and would clearly be inappropriate in the setting of hypoxia. This consideration questions the recent suggestion of Stephenson and Variend" that necrosis of brown adipose tissue in cot death results from continued metabolic activity in hypoxic tissue. The viral infective cause suggested by Grist and Urquhart seems more plausible, ${ }^{12}$ given the long known attractiveness of brown adipose tissue as a site of primary viral multiplication. ${ }^{13}$

The oxygen uptake of maximally stimulated brown adipose tissue in $23^{\circ} \mathrm{C}$ acclimated mice is about $1.5 \mathrm{ml}$ $\mathrm{O}_{2}$ /minute, equivalent to a heat production of 8-10 calories/minute/g tissue. ${ }^{14}$ If Hull's figure ${ }^{15}$ of $30 \mathrm{~g}$ of brown adipose tissue in a neonate is accepted, then the heat output under maximal acute stimulation, but without any long term trophic stimulation, would be about 250 calories/minute. Thermogenesis of this order would increase the basal metabolic rate of a neonate by about $200 \%$-more than sufficient to account for the observed metabolic response to cold temperature or noradrenaline infusion, and enough to raise core temperature by $5-6^{\circ} \mathrm{C} /$ hour. The lower thermogenesis of brown adipose tissue of adult rats, acclimated to a temperature of $33^{\circ} \mathrm{C}$ and stimulated by noradrenaline measured at $0.4 \mathrm{ml} \mathrm{O}_{2} /$ minute $/ \mathrm{g}$ by Foster and Frydman, ${ }^{16}$ would still produce an almost $100 \%$ increase in the metabolism of an infant with $30 \mathrm{~g}$ brown adipose tissue. If this occurred inappropriately and suddenly in a well clothed and insulated infant, the core temperature might be raised to dangerous levels and induce apnoea. Our biochemical findings indicate that this might have occurred in our two cases of pyrexial cot death. This conclusion can be made, irrespective of a separate question, which cannot be answered at present: is brown adipose tissue equally active in infants who have died of other causes?

We thank Professor A Gresham, department of morbid anatomy, School of Clinical Medicine, University of Cambridge, for his encouragement and help in providing rapid access to samples.

\section{References}

1 Stanton AN. Overheating and cot death. Lancet 1984;ii:1199-201.

2 Nelson EAS, Taylor BJ, Weatherall IL. Sleeping position and infant bedding may predispose to hyperthermia and the sudden infant death syndrome. Lancet 1989; i:199-201.

3 Naeye RL. Evidences of antecedent chronic hypoxia and hypoxaemia. In: Robinson RR, ed. FE Camps Symposium on SIDS, Toronto. 1974:1-6.

4 Yonetani T, Ray GS. Studies on cytochrome oxidase. VI. Kinetics of the aerobic oxidation of ferrocytochrome $\mathrm{c}$ by cytochrome oxidase. J Biol Chem 1965;24:3392-8.

5 Goodbody AE, Trayhurn P. Studies on the activity of brown adipose tissue in suckling, pre-obese ob/ob mice. Biochim Biophys Acta 1982;680:119-26. 
6 Lean MEJ, James WPT, Jennings G, Trayhurn P. Brown adipose tissue uncoupling protein in infants, children and adult humans. Clin Sci 1986;71:291-7.

7 Hatai S. On the presence in human embryos of an interscapular gland corresponding to the so-called hibernating gland of lower mammals. Anat Anz 1902;21:369-73.

8 Lean MEJ, James WPT, Jennings G, Trayhurn P. Brown adipose tissue in patients with phaeochromocytoma. Int $J$ Obesity 1986;10:219-27.

9 Ricquier D, Mory G, Bouillaud F, Thibault J, Weissenbach J. Rapid increase of mitochondrial uncoupling protein and its mRNA in stimulated brown adipose tissue. FEBS Letters 1984;178:240-4.

10 Oliver TK, Karlberg P. The effects of environmental temperature and $15 \%$ oxygen on the gaseous metabolism of newborn infants. Acta Paed Scand 1962;(Suppl 140):51-3.

11 Stephenson TJ, Variend S. Visceral brown fat necrosis in postperinatal mortality. J Clin Pathol 1987;40:896-900.

12 Grist NR, Urquhart GED. Brown fat and sudden death. J Clin Pathol 1987;41:597-8.

13 Schwartzman G, Aronson SM. Participation of brown fat in the pathogenesis of experimental poliomyelitis of monkeys. Proc Soc Exp Biol Med 1954;86:767-71.

14 Thurlby PL, Trayhurn P. Regional blood flow in genetically obese (ob/ob) mice. The importance of brown adipose tissue to the reduced energy expenditure on non shivering thermogenesis. Pflugers Arch 1980;385:193-201.

15 Hull D. Brown adipose tissue and the newborn infant's response to cold. In: Philipp EE, Barnes J, Newton M, eds. Scientific foundations of obstetrics and gynaecology. 2nd edition. London: Heinemann Medical Books, 1977:545-50.

16 Foster DO, Frydman ML. Nonshivering thermogenesis in the rat II. Measurements of blood flow with microspheres point to brown adipose tissue as the dominant site of the calorigenesis induced by noradrenaline. Can $J$ Physiol Pharmacol 1978;57:257-70.

17 Ashwell M, Jennings G, Richard D, Stirling DM, Trayhurn P. Effect of acclimation temperature on the concentration of the mitochondrial "uncoupling" protein measured by radioimmunoassay in mouse brown adipose tissue. FEBS Letters 1983;161:108-13.

Requests for reprints to: Dr M E J Lean, Diabetic Clinic, Woolmanhill Hospital, Aberdeen Royal Infirmary, Aberdeen AB9 IGS, Scotland. 